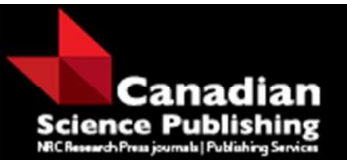

Canadian Journal of Forest Research

Revue canadienne de recherche forestière

\title{
Long-term fire history of maple (Acer) forest sites in the central St. Lawrence Lowland, Quebec
}

\begin{tabular}{|r|l|}
\hline Journal: & Canadian Journal of Forest Research \\
\hline Manuscript ID & cjfr-2015-0305.R2 \\
\hline Manuscript Type: & Article \\
\hline Date Submitted by the Author: & 11 -Mar-2016 \\
\hline Complete List of Authors: & $\begin{array}{l}\text { Payette, Serge; Université Laval } \\
\text { Pilon, Vanessa; Université Laval } \\
\text { Couillard, Pierre-Luc; Ministère des Forêts, de la Faune et des Parcs, } \\
\text { Direction des inventaires forestiers } \\
\text { Frégeau, Mathieu; Université Laval }\end{array}$ \\
\hline Keyword: & Fire, Sugar maple, Red maple, Eastern hemlock, Succession \\
\hline
\end{tabular}

\section{SCHOLARONE \\ Manuscripts}


1 Long-term fire history of maple (Acer) forest sites in the central St.

2 Lawrence Lowland, Quebec

3

4

5

6 Serge Payette $^{1,3}$, Vanessa Pilon $^{1}$, Pierre-Luc Couillard ${ }^{2}$ et Mathieu Frégeau ${ }^{1}$

7 1. Département de biologie and Centre d'études nordiques, Université Laval, 1045, av. de

8 la Médecine, local 3058, Québec (Québec), G1V 0A6

9 2. Direction des inventaires forestiers, Ministère des Forêts, de la Faune et des Parcs,

10 Gouvernement du Québec, 700 4e ave ouest, local A108, Québec (Qc), G1H 6R1

113 . Corresponding author (serge.payette@bio.ulaval.ca)

12

15 Email address of authors:

16 Serge.Payette@bio.ulaval.ca

17 Vanessa-Joanne.Pilon.1@ulaval.ca

18 Pierre-Luc.Couillard@mffp.gouv.qc.ca

19 Mathieu.Fregeau.1@ulaval.ca 
20 Abstract: In the St-Lawrence lowlands, sugar maple (Acer saccharum) is considered

21 the dominant species of old-growth deciduous forests while red maple (Acer rubrum)

22 tends to dominate sites recently disturbed by logging and agricultural practices.

23 Considering that the long-term influence of fire is not documented for such stands, we 24 reconstructed the postglacial tree composition (as deduced from charcoal species) and

25 fire history of a sugar maple (Ste-Françoise area) and a red maple (Villeroy area) stand

26 located southwest of Quebec City (Canada). The sites are $10 \mathrm{~km}$ apart and show

27 contrasting soil and landform features. Using botanical identification and ${ }^{14} \mathrm{C}$ dating of

28 soil macrocharcoal, we found that fire struck both maple stands 14-20 times since

29 deglaciation. Most fires occurred in the early Holocene and during the last 2000 years,

30 the mid Holocene being a low frequency or fire-free period. During the last 1600 years,

31 the Villeroy stand shifted from a Tsuga canadensis/conifer forest to a mixed forest and,

32 most recently, to a red maple stand as fire became more frequent, possibly due to human

33 activities of the last 400 years. This study confirms the influence of fire on the

34 development of maple forests. Fire should be considered as an important disturbance

35 factor in the dynamics of temperate deciduous/mixed forests. 
36 Résumé : L'érable à sucre (Acer saccharum) est considéré comme une espèce

37 dominante des vieilles forêts à feuillage décidu des basses terres de la vallée du Saint-

38 Laurent, alors que l'érable rouge (Acer rubrum) a tendance à occuper les stations

39 récemment perturbées par l'activité forestière et l'activité agricole. Étant donné que

40 l'influence à long terme des feux n'est pas documentée chez les érablières, nous avons

41 procédé à la reconstitution de l'histoire des feux et de la composition botanique (en

42 partie, à l'aide des charbons de bois) de deux stations actuellement occupées par une

43 érablière à érable à sucre (localité de Ste-Françoise) et une érablière à érable rouge

44 (localité de Villeroy) situées au sud-ouest de la ville de Québec. Les deux stations sont

45 situées à $10 \mathrm{~km}$ l'une de l'autre et diffèrent quant aux caractéristiques

46 géomorphologiques et pédologiques. D'après les données radiométriques et botaniques

47 des macrorestes de charbons de bois échantillonnés, 14 à 20 feux ont affecté les deux

48 stations d'érable depuis la déglaciation de la région. La plupart des feux sont apparus au

49 début de l'Holocène et au cours des derniers 2000 ans, alors que l'Holocène moyen a été

50 une période sans feu ou de faible fréquence de feu. Au cours des derniers 1600 ans à

51 Villeroy, une forêt de conifères dominée par la pruche du Canada (Tsuga canadensis)

52 s'est transformée en forêt mixte et, plus récemment, en érablière à érable rouge alors que

53 le feu est devenu plus fréquent au cours des 400 dernières années possiblement à cause de

54 l'activité humaine. Notre étude confirme l'influence déterminante du feu sur le

55 développement des érablières. Nous en concluons que le feu constitue un facteur de

56 perturbation d'importance jouant un rôle dans la dynamique des forêts mixtes et décidues

57 des régions tempérées froides. 


\section{$58 \quad$ Introduction}

Maple (Acer) forests are among the main hardwood forest types of eastern North

60 America (Grandtner 1966; Rowe 1972; Bouchard and Maycock 1978; Brisson et al.

61 1988; Barbour and Billings 1999). Of the several maple species of southern Quebec and

62 New England, sugar maple (Acer saccharum) stands as a dominant canopy tree of mature

63 and old-growth deciduous forests (Grandtner 1966; Girardin 1969; Brown 1981; Foster et

64 al. 1998; Cogbill 2000), whereas red maple (Acer rubrum) dominates disturbed,

65 secondary forests under mesic and wet soil conditions (Bergeron et al. 1988; St-Jacques

66 and Gagnon 1988; Gauthier and Gagnon 1990; Abrams 1998). The two maple species are

67 in a constant flux of population changes across their natural range limit since the early

68 times of European settlement in close association with stand disturbances (Whitney 1994;

69 Abrams 1998; Foster et al. 1998). Sugar maple has lost terrain in New England because

70 of extensive agricultural settlement and logging (Foster et al. 1998). In contrast, red

71 maple increased significantly its ecological range over the last centuries from wetlands to

72 well-drained forest lands because of repetitive disturbance events caused by logging and

73 land clearing (Abrams 1998).

Fire as a stand disturbance in deciduous and mixed forests of the temperate zone

75 of eastern North America was often considered of secondary importance and occasional,

76 mostly man-made, and caused by early colonist campfires and aboriginal fires (Lorimer

77 1977; Oliver and Stephens 1977). Fire disturbance is also viewed as a successional factor

78 in the dynamics of several hardwood and mixed forests of New England (Henry and

79 Swan 1974; Foster et al. 1998) and southern Quebec, although logging and land clearing

80 remain the principal disturbances reported for forest ecosystems of the St. Lawrence 
81 valley (Grandtner 1966; Bergeron et al. 1988; St-Jacques and Gagnon 1988). In contrast,

82 sugar maple forests at their northern distribution limit have been influenced by fire at

83 least over the last two millennia (Pilon and Payette 2015). Fire was identified as a 84 developmental factor in the dynamics of northern sugar maple forests in the

85 Témiscamingue and Saguenay areas. The paleoecological record of soil charcoal from

86 maple forest sites also shows the tolerance and resilience of sugar maple to recurrent fires

87 during the Holocene (Talon et al. 2005; Pilon and Payette 2015).

Maple forests are a major component of the diversified forest mosaic of the St.

89 Lawrence Lowland, which is dominated by early-successional and secondary forest

90 stands. The influence of fire on the composition and stability of these ecosystems at the

91 site scale and at different temporal scales is still largely unknown despite the numerous

92 stand surveys done over the past decades. This lack of knowledge on the dynamics of

93 maple sites prompted this study whose main objective is to reconstruct the postglacial fire

94 history and, to some extent, the plant composition of two representative sites presently

95 occupied by sugar maple and red maple in the central St. Lawrence lowland, near Quebec

96 City. To do so, macrocharcoal analysis of forest soils was used for this reconstruction.

97 The analysis is based on the botanical identification and radiocarbon dating of charcoal

98 fragments retrieved from the soil surface and the mineral solum of two maple forest sites

99 dominated by sugar maple and red maple, respectively. 


\section{Study sites}

The two maple sites are located southwest of Quebec City (Canada), in the central

103 St. Lawrence Lowland (Table 1). The Villeroy site is part of a large parabolic-dune field 104 peatland complex formed at the Pleistocene-Holocene transition (Filion 1987). Plants of

105 the Villeroy forest are colonizing well-drained, acidic podzolized soils composed of 106 medium to fine sands. The Ste-Françoise site is situated about $10 \mathrm{~km}$ from the Villeroy 107 site and extends on a relatively flat fluvio-marine terrace composed of reworked till. The 108 loamy soil of this site is an acidic and moderately drained podzol.

The Ste-Françoise stand is dominated by sugar maple and yellow birch (Betula 110 alleghaniensis). A small number of mature red maple, basswood (Tilia americana) trees 111 and American beech (Fagus grandifolia), and juvenile balsam fir (Abies balsamea), 112 white ash (Fraxinus americana) and striped maple (Acer pensylvanicum) (Table 2) are 113 distributed as companion species. Red maple is the dominant canopy species of the 114 Villeroy stand with several other tree species as companions, including sugar maple, 115 American beech, yellow birch, large-toothed aspen (Populus grandidentata) and balsam 116 fir (Table 2).

\section{Methods}

\section{Sampling of size structure and charcoal}

In order to reconstruct the fire history of the two maple sites, a description of the

121 structure and composition of the two stands was most indicated. The size structure 122 (diameter at breast height, dbh) of all tree stems distributed in each maple stand was 
123 recorded systematically in $1000-\mathrm{m}^{2}$ sample plot. Stems $<2 \mathrm{~cm}$ dbh were counted in 124 subplots totalling $50 \mathrm{~m}^{2}$ at the Ste-Françoise site and $300 \mathrm{~m}^{2}$ at the Villeroy site. The total 125 number of seedlings and saplings in each stand was extrapolated based on the surface of 126 the subplots.

The Ste-Françoise site was sampled in June 2013. A rectangular plot (20 m x 50 m) was positioned at about $30 \mathrm{~m}$ from the border forest. Charcoal sampling included 25 129 microsites with 22 microsites distributed along the upper and lower lines and the other 130 microsites at the center of the plot. At the Villeroy site, the first field survey was executed 131 in 2012 and included the sampling of 10 microsites positioned every $5 \mathrm{~m}$ along a line at 132 the center of the stand. In 2013, 15 supplementary microsites were added and were 133 distributed every $5 \mathrm{~m}$ along a $75-\mathrm{m}$ long line for a total of 25 sampled microsites.

134 A $20 \mathrm{~cm} \times 20 \mathrm{~cm}$ sample of the organic horizon, from the soil surface to topmost 135 part of the mineral soil, was used for charcoal extraction at each microsite. The thickness 136 of each organic sample was measured before being sampled. In 2012, a mineral soil 137 sample beneath the organic horizon was taken at each microsite of the Villeroy site with a 138 soil corer allowing the recovery of $750 \mathrm{~cm}^{3}$ of soil. Two superposed mineral soil samples 139 (solum A and solum B) were taken in the other 15 microsites sampled at the Villeroy site 140 in 2013 as in the Ste-Françoise site except for three of them because of sampling 141 problems. Solum A and B samples are from soil cores taken at 0-15 cm and 15-30 cm 142 depth, respectively. Charcoal fragments were also extracted from buried organic horizons 143 along a nearby forest road and also in the Villeroy peatland adjoining the sand dunes. 
Each sample of the organic horizon (surface compartment) and the mineral soil

145 (mineral compartment) was placed for 12 hours in a solution of $2-5 \% \mathrm{NaOH}$ to disperse

146 the soil aggregates and to eliminate the organic matter during screening. The samples

147 were cleaned using running water over $2 \mathrm{~mm}$ and $4 \mathrm{~mm}$ mesh screens. All charcoal

148 fragments were extracted manually under a binocular microscope and dried at room

149 temperature before being weighed. The charcoal fragments are $>2 \mathrm{~mm}$, which indicates

150 that they were formed and deposited in the sampled sites and that they were not

151 transported over long distances (Ohlson and Tryterud 2000). The fragments were

152 sectioned to analyze the three anatomical planes under an incident light microscope at

153 magnifications of 200x and 500x. The identification criteria described by Hoadley

154 (1990), Inside Wood (2004) and Panshin and de Zeeuw (1980), as well as the charcoal

155 collection of the Centre d'Études Nordiques (Université Laval, Québec), were used for

156 the botanical identification of all the charcoal fragments at the genus level, and the

157 species level when possible. The preservation state of the fragments (vitrification,

158 reaction wood, physical decay), their small size as well as the orange deposits filling the

159 wood cells were the main factors reducing our ability to identify the charcoal fragments.

161 Charcoal dating and fire history

162 The fragments were selected for ${ }^{14} \mathrm{C}$ dating (AMS method: accelerator mass 163 spectrometry) according to charcoal species/genus present in the sites and to position in 164 the two plots. Charcoal fragments selected were pretreated to $\mathrm{CO}_{2}$ in the ${ }^{14} \mathrm{C}$ laboratory of 165 the Centre d'Études Nordiques and dated at the Keck Carbon Cycle AMS facility 166 (University of California, Irvine, California, USA) or at the Center for Applied Isotope 167 Studies (University of Georgia, Athens, Georgia, USA). The software Calib7.02 (Stuiver 
168 et al. 2013) and the database IntCal13.14C (Reimer et al. 2013) and UWSingleYEAR98

169 (for dates $<71$ years BP) (Stuiver et al. 1998) were used for the calibration of the ${ }^{14} \mathrm{C}$

170 dates in calendar years. For each ${ }^{14} \mathrm{C}$ date $( \pm 2$ standard deviations), we have considered

171 the distribution of the calendar ages according to their associated probabilities given by

172 the software. The distribution of the calendar ages is generally divided in probabilistic

173 states because of the variable content of atmospheric ${ }^{14} \mathrm{C}$ through time closely associated 174 with solar activity (Solanki et al. 2004). The mean of the interval having the highest

175 probability was used for the determination of the calendar age of each dated sample plus

17665 years added to the standard 0 year BP (1950 AD). The charcoal dates with overlapping

177 calendar years were considered as originating from the same fire. (see supplementary

178 material for details) The dated charcoal fragments were used to calculate fire intervals

179 corresponding to the number of non-overlapping calendar years that separates fire events.

180 Based on all the fire events identified, a long term fire-frequency history was constructed

181 for the two sites. All the calibrated radiocarbon dates were pooled in a cumulative

182 probability analysis using the sum-probabilities option in CALIB 7.02 (Stuiver et al.

183 2013) to plot the probability that a given event occurred at a particular time in order to

184 visualize the fire chronology on the Holocene time scale (Lafortune et al. 2006; Payette et

185 al. 2012). This method sums the probabilities of all dates and therefore takes into account 186 the uncertainties inherent to radiocarbon dating.

187 Forest stands are continuously affected by disturbance events, so the distribution 188 of charcoal fragments in the surface compartment and the soil compartment is not 189 stratified (Carcaillet 2001) as it is in the sedimentary environments of dunes, peatlands 190 and lakes (Filion 1984; Tolonen 1985; Bradbury 1996). Given that the distribution of 191 charcoal in the forest environment is continuously affected by blowdowns and other soil 
192 disturbances modifying the original soil horizonation, it is necessary to date the greatest 193 number of charcoal fragments to record all the fire events that occurred at the site. 194 Because one cannot date all the charcoal fragments, and the fire events, accumulated in 195 the soil since the initial establishment of the forest after deglaciation, it is now common 196 practice to use an indirect method to evaluate the total number of fires that occurred at a 197 site (de Lafontaine and Payette 2012). The random sampling of charcoal fragments does 198 not assure that all fires will be detected, thus justifying the construction of an 199 accumulation curve to know whether the number of detected fires corresponds to the 200 number of all the fires that occurred in the maple sites. The accumulation curve relates 201 the number of fires detected according to the number of charcoal pieces dated. When the 202 curve forms an asymptote, it suggests that most of the fires that occurred at the site have 203 been theoretically detected. The accumulation curve of each site was calculated with 204 accumresult() function using the random method of the BiodiversityR package in the $\mathrm{R}$ 205 software (Kindt and Coe 2005; R Development Core Team 2011). This function plots 206100 accumulation curves by randomly resampling from the radiocarbon dates of a given 207 site. The mean accumulation curve is then calculated from these 100 curves and plotted. 208 An indicator of the number of estimated fires was calculated from the mean accumulation 209 curve of each site. An index was produced based on a nonlinear regression of the mean 210 number of fires detected in relation to the number of dated charcoal pieces. The nonlinear 211 regression $F(n)=F(\max )\left(1-\mathrm{e}^{\mathrm{kn}}\right)$ corresponds to the number of fires detected, $n$ the 212 number of charcoal pieces dated, $K$ the constant controlling the shape of the curve, and $213 F \max$ the index of the number of fires. The $F \max$ index and the constant $K$ were 214 calculated using the nls() function of R (R Development Core Team 2011). The Fmax 215 index corresponds to the factor controlling the flattening of the exponential negative 
216 curve that is considered here as an estimator of the actual number of fires (Soberon and

217 Llorente 1993; Payette et al. 2012; Frégeau et al. 2015).

218

219 Results

220 Structure of the Ste-Françoise sugar maple forest

The size structure includes about 4400 stems distributed among 7 tree species

222 present in the stand. Sugar maple is the dominant species and includes the largest and

223 tallest stems of the canopy and the lower tree strata in the form of a flattened bell-shape

224 curve (Figure 1). Yellow birch is mostly distributed in the medium and small size classes.

225 The regeneration layer $(<2 \mathrm{~cm} \mathrm{dbh})$ is composed of several sugar maple, red maple and

226 yellow birch, with occasional American beech, white ash and balsam fir seedlings.

227 The forest floor is covered by a leaf litter and a thick organic horizon accumulated

228 above a thin horizon composed of charcoal pieces. A small number of dead tree stems

229 and branches are distributed on the soil surface. These features indicate that the maple

230 forest originated recently from a fire. The oldest stem out of 18 trees cored at $30 \mathrm{~cm}$

231 above ground established in the 1880s, which suggests an age of 130-140 years for the

232 last fire to have occurred at the site.

233

234 Structure of the Villeroy red maple forest

235 The size structure of the stand includes more than 2250 individuals distributed 236 among 6 tree species with the largest trees being red maples (Figure 1). The latter species

237 dominates most size classes $>6 \mathrm{~cm}$, although sugar maple is also well distributed in theses 
238 classes but without reaching the largest sizes. The advanced generation is equally shared by 239 sugar maple (50\%) and red maple (48\%). A small number of Amercian beech (1.3\%), 240 balsam fir $(<1 \%)$ and large-toothed aspen $(<1 \%)$ are also part of the advanced regeneration

241 layer. Balsam fir occupies only this layer whereas the other tree species are present in the 242 upper layers.

243 The forest floor is covered by a thick litter accumulated above an horizon of 244 charcoal pieces. Whereas the forest is composed of several layers with the upper tree 245 layer $(>15-20 \mathrm{~m}$ height $)$ and the shrub layer $(<2 \mathrm{~m}$ height $)$ as the most important, no 246 tree stems nor branches lay on the ground except for a limited number of small stems

247 recently fallen on the ground. The soil surface of the forest is largely open in contrast to 248 that of forests which have not been disturbed for a long time, which indicates that the 249 stand originated from a relatively recent fire. The oldest stem out of 12 trees cored at 30 $250 \mathrm{~cm}$ above ground established in the 1920 s or the early 1930 s probably after man-made 251 bush fires (Bureau 1968; Payette et al. 2013).

\section{Charcoal species of the Ste-Françoise site}

253 Both soil compartments contain several charcoal pieces, the latter being more abundant at 254 the soil surface than in the mineral soil (Table 3). Charcoal from the soil surface are 255 composed of angiosperms, including maple and undetermined species. Carbonized fungi 256 also are common on the ground as in other sugar maple stands of Quebec (Pilon and 257 Payette 2015). Only a small amount of charcoal pieces were recovered from the mineral 258 soil, about 4 times more in the upper part than in the lower part of the mineral solum. 259 Half of the charcoal pieces are of unknown identity, whereas the majority of the other 260 pieces are angiosperms. Three charcoal pieces are conifers, including a Picea/Larix 
261 fragment. Two birch, 22 broadleaf (including several thin pieces showing only one 262 longitudinal axis) and 24 other charcoal pieces corresponding to bark were recovered. 263 Broadleaf charcoals with spiral thickenings, a structure present in the vessel elements, 264 correspond possibly to maple species. The latter fragments break down as lamellar 265 structures showing only one plane and, therefore, could not be properly identified. 266 Several wood sections possess parenchyma rays of 3 to 4 cells wide possibly 267 corresponding to soft maples (either red maple or shrub maple). Other pieces of similar 268 structures display larger parenchyma rays (5-6 cells) which may be indicative of sugar 269 maple wood. One charcoal piece containing rays of 7 cells large was identified as sugar 270 maple. All the charcoal pieces with a lamellar structure originated from dead wood on the 271 forest floor and are dominating the charcoal assemblage of the surface compartment.

272 Given the neat structure of the dead wood population, it is assumed that the age of the fire 273 is rather close to the age of the wood that produced the charcoal. The saprophytic fungus 274 Annulohypoxylon multiforme is also part of the charcoal assemblage of the surface 275 compartment, which testifies that the last fire burned woody debris (stems and branches) 276 of the forest floor.

\section{The Ste-Françoise fires}

279 Fourteen fire events were identified at the site over the last 9900 years (Table 4).

280 Fires that occurred since $2500 \mathrm{cal}$ yr BP are represented by charcoal pieces derived from 281 broadleaf species (including one sugar maple charcoal) and bark. Several charcoal 282 fragments are of the lamellar type as described earlier, i.e., thin sections showing only 283 one longitudinal axis. Fires occurring prior to $7400 \mathrm{cal}$ yr BP are represented by 284 broadleaf (including birch), vitrified and conifer (including Picea/Larix laricina) charcoal 
285 pieces. The oldest fire has been recorded by a conifer charcoal likely originating from a 286 small stem or a branch. The most frequent fires occurred during the last 2500 years, 287 particularly the last 1000 years, with a mean fire interval of $340 \pm 275$ years and $185 \pm 80$ 288 years, respectively. A long quiescent, fire-free period ranged between 7400 and 2500 cal 289 yr BP, whereas the early Holocene between 9900 and 7400 cal yr BP featured several 290 fires succeeding at a mean interval of $495 \pm 245$ years. According to the accumulation 291 curve of all the charcoal dates, 18 fire events ( standard error $=0.11$ ) could have occurred 292 at the site during the Holocene, i.e., 4 fire events more than the number of fire events 293 recorded by all the dated charcoal pieces (Figure 2).

The organic horizon of 18 out of the 25 microsites contain several charcoal pieces

297 (Table 5). Charcoal was also found in 14 out of the 25 cores corresponding to the first 15 $298 \mathrm{~cm}$ of mineral soil (samples of solum A) and 6 out of the 15 cores of samples of solum B. 299 The number of charcoal pieces is 20 times greater in solum A cores than in solum B 300 cores. Paleosols associated with eolian activities were not found in the sampling area 301 except along a nearby forest road.

302 Broadleaf charcoal pieces of the surface compartment correspond to small stem and 303 branch fragments as well as bark and pith. It was not possible to check for the presence of 304 xylem structure because of the small size of the charcoal pieces. Soft maple charcoal 305 pieces are distributed in several microsites including 5 pieces showing a lamellar 306 structure similar to that of charcoal pieces dominating the assemblage of the surface 307 compartment of the Ste-Françoise site. Charcoals of the surface compartment display an 
anatomical structure similar to that of soft maple (e.g., Acer rubrum, Acer pensylvanicum or Acer spicatum), species of the Rosaceae family, basswood (Tilia Americana) and sugar maple. Several Populus charcoal pieces were found in one microsite only, and they probably originated from one tree individual. The 29 birch charcoal pieces of the surface compartment also occurred in one microsite probably originated from one tree individual. Eastern hemlock (Tsuga canadensis) charcoal pieces were found in one microsite of the mineral compartment and in several microsites of the surface compartment. Several charcoal pieces identified to Tsuga-Larix, Tsuga-Abies, Tsuga-Abies-Thuja are probably eastern hemlock charcoal, but their small size or degree of decay were such that the presence of the other conifer species could not be discarded. In contrast, charcoal pieces of balsam fir were identified and it is probable that charcoal of this species is represented in the latter groups of charcoal pieces. Eastern hemlock and balsam fir are conifer species showing similar anatomical characters. A large part of the sampled charcoal pieces do not show secondary xylem structures (tracheids, parenchyma rays, vessel elements, etc.) and it is presumed that these fragments were formed after the burning of bark and stem (or branch) cortex or another structure.

White pine (Pinus strobus) and aspen stems were found buried in the sandy road bordering the maple stand. The pine stem was dated 1320 cal yr BP (UCIAMS-129791, UL-4217: $1350 \pm 15$ yr BP). Fifty seven charcoal pieces were recovered from the organic horizon buried beneath the forest road. All the charcoal pieces $\geq 2.5 \mathrm{mg}$ were analyzed under the microscope: 8 pieces were vitrified and 8 other pieces were bark, parenchyma and cortex fragments. Six pieces are soft maples or other broadleaf samples that contain spiral thickenings in the vessel elements. Finally, 8 pieces are conifers, including at least one spruce (Picea) charcoal. 


\section{The Villeroy fires}

Sixteen fire events were recorded at the Villeroy site over the last 9700 years

335 (Table 6). Two long fire-free periods occurred between 8400 and 5000 cal yr BP and 3364100 and 1600 cal yr BP, respectively. Most dated charcoal fragments refer to the 3 most 337 recent fires $(85, \sim 150$ and 250 cal yr BP). These fires were recorded from charcoal of the 338 forest stand, the organic horizons beneath the forest road and in peat layers located 339 nearby. The charcoal pieces from these fire events are forming a diversified botanical 340 assemblage with Tsuga, Acer and Populus. The 150-yr fire event also is represented by 341 spruce, balsam fir and American yew (Taxus canadensis). The dating of 5 charcoal pieces 342 of the organic horizon buried beneath the forest road refers to 3 different fire events 343 including a 550 cal yr BP fire which was not detected along the sampling transect. Four 344 superposed organic horizons buried in the peat deposits near the maple stand (Table 6) 345 contained several conifer (Picea sp. - Larix laricina) fragments. The radiocarbon dates of 346 charcoal fragments contained in these stratigraphilly distinct organic horizons resulted 347 from 3 different fire events dated to 150, 250 and 1570 cal yr BP. Fires dated between 348500 and $9700 \mathrm{cal}$ yr BP are less represented in the global charcoal assemblage. The oldest 349 fires (> 4000 cal yr BP) are represented by altered (vitrified, mineralized, etc.) charcoal 350 pieces of broadleaf and conifer species. The most frequent fires occurred over the last 3511600 years with a mean fire interval of $215 \pm 190$ years. However, the mean fire interval 352 of the last 600 years was $120 \pm 55$ years. The number of estimated fires by the 353 accumulation curve is 20 (standard error $=0.71$ ), i.e. 4 fire events more than the number 354 of fire events recorded by all the dated charcoal pieces (Figure 3). 


\section{Discussion}

Our data show that the two maple forest sites have burned repetitively over the

years. The two maple sites have recorded about the same number of fires during the

359 Holocene, i.e., 14 and 16 fires. It is probable that a greater number of fires may have

360 struck both sites during this period, but not more than 18 to 20 fires according to the 361 accumulation curves.

The fire history of both maple sites is relatively similar. Two main periods of fire activity were recorded at the Ste-Françoise site, the oldest period ranging from 9900 to

3647500 years before present and the second period from 2500 years ago to present time. A 365 period of 5000 years of quiescent conditions on both sides of the mid-Holocene separated 366 the two periods. It is possible that sporadic fires affected the site during the mid367 Holocene, but there is no evidence to confirm this. Fire frequency at the Villeroy site is 368 much alike that of the Ste-Françoise site. Two periods of fire activity occurred between 3699700 and $8500 \mathrm{cal} \mathrm{yr} \mathrm{BP}$ and $1600 \mathrm{cal}$ yr BP to present, respectively. The main difference

370 with the Ste-Françoise site is the incidence of 3 fire events between 5000 and 4150 cal yr

371 BP. The several thousand years that have passed on both sides of the mid-Holocene were 372 thus characterized by a period of relative low fire activity. The mid-Holocene coincides 373 with the decline of eastern hemlock in the St-Flavien area, near the Villeroy site, between 3745700 and 4250 cal yr BP (Bhiry and Filion 1996a,b). The oldest charcoal pieces of the 375 Villeroy site (9900 years old) are buried into the upper podzolic solum of the dune soils, 376 confirming the old age of the parabolic dunes in this region which were formedat the 377 transition between the Pleistocene and the Holocene, about $11500-10000$ cal yr BP 378 (Filion 1987). 
At the scale of the southwestern part of the Quebec City region, fires were 380 frequent during the early Holocene in the study sites, in the lac Yamaska region located 381 less than $100 \mathrm{~km}$ south of the Villeroy site (Carcaillet and Richard 2000) and in early 382 Holocene forest sites now fossilized beneath peat layers of the Grande-Tourbière-de383 Villeroy and the Grande Plée bleue bog near the vicinity of St-Louis-de-Pintendre 384 (Lavoie et al. 2012; Lavoie and Colpron-Tremblay 2013). Beneath the peat deposits of 385 these bogs, macrocharcoal layers confirm the past development of forests which were 386 progressively paludified and transformed into the extensive ombrotrophic peatlands as 387 they occur today. Fire activity was probably associated with dry climatic conditions 388 which prevailed during the deglaciation of the St. Lawrence valley (Filion et al. 2009). 389 The deciduous forest of the Tantaré site north of Quebec City also recorded a high fire 390 frequency from the early to mid-Holocene, between 10500 and 6500 cal yr BP (Talon et 391 al. 2005; figure 4).

The drier climate of the early Holocene is also responsible for the edification of 393 the extensive sand dune complex distributed across the St. Lawrence Lowland (Filion 394 1987), including the Villeroy dunes on which the study maple forest and the bordering 395 peatland were established (Lavoie and Colpron-Tremblay 2013; Payette et al. 2013). 396 Eolian activity in the region declined around 9000-8600 cal yr BP, and stabilization of 397 the regional sand dune complex occurred around 8200 cal yr BP which coincided with 398 the disintegration of the Laurentide Ice above Hudson Bay and its correlative loss of 399 control on the dry climate which was previously generated by its enormous mass (Filion 400 1987; Barber et al. 1999). The charcoal fragments of the 5 oldest fires of the Villeroy site 401 correspond to an early establishment of woody species on stabilized dunes. Because these 
402 charcoal fragments were found in the uppermost $15 \mathrm{~cm}$ of the podzol soil, it is probable 403 that dune stabilization occurred before 9700 cal yr BP in our study site.

The mid-Holocene does not seem to have been a fire-prone period when one considers the fire records of the Ste-Françoise and the Villeroy sites, similar to the fire 406 activities that prevailed at the Tantaré site, the Rivière-Éternité site (Saguenay area) 407 (Figure 4), and the lac Yamaska region (Carcaillet and Richard 2000). The climate during 408 this period was possibly more humid, at least during the summer season, which reduces 409 fire ignition and propagation. Fire frequency increased after 3000-2000 cal yr BP in the 410 studied sites and the Rivière-Éternité site, except at the Tantaré site which has not been 411 impacted by fire since 6000 cal yr BP (Talon et al. 2005; figure 4). To our knowledge, 412 there exists no empirical evidence, climatic and archeological, to explain the increased 413 fire frequency at this time. On the other hand, the higher fire frequency of the last 400 414 years in all the study sites may have been caused, at least in part, by human activities. 415 The central St. Lawrence lowland was among the first pristine forest land areas to be 416 cleared for agricultural purposes during the French regime (Courville 1996). The areas 417 surrounding the Ste-Françoise and the Villeroy settlements were burned repetitively over 418 the last centuries, particularly during the period of agricultural settlement which generally 419 followed logging and other man-made activities in the region (Bureau 1968).

421 Holocene and the late Holocene were periods of high fire frequency before and after the 422 quiescent period of the mid-Holocene. Long fire intervals during the last 10000 years 423 suggests the edification of stable forest landscape during several thousand years, a 424 situation which reduces the establishment of post-fire pioneer species. It is only when 
425 repetitive fires are occurring that such species are able to invade disturbed sites such as is 426 the case presently in our two sites.

427 It is possible that most fires having struck the Ste-Françoise and the Villeroy 428 sites were limited spatially. As a result, we suggest that the regional vegetation 429 surrounding our maple sites was possibly forming a mosaic of small, old-aged forest 430 stands regenerated after fire until the onset of the French regime or later during the period 431 of extensive settlement (Bureau, 1968).

Only limited information was gained on the botanical composition of the plant 433 cover affected by fire at the Ste-Françoise site because of the lamellar structure (one 434 plane instead of the 3 planes usually visible on $3 \mathrm{D}$ charcoal pieces) of most charcoal 435 pieces. However, according to the relatively small set of charcoal pieces identified, it is 436 possible that a mixed-conifer and broadleaf forest, including birch, prevailed between 4379900 and 7500 cal yr BP. Pollen data of the St-Flavien-de-Lotbinière site, near the 438 Villeroy site, suggest that mid-Holocene forests were represented by mixed stands 439 dominated by angiosperm and gymnosperm species, including sugar maple, yellow birch 440 and elm (Ulmus), along with a maximum representation of white pine and eastern 441 hemlock (Filion and Quinty 1993; Filion et al. 2009). A second development of broadleaf 442 or mixed forests, including the arrival of sugar maple at least 700-800 years ago, 443 dominated the Ste-Françoise site during the last 2500 years. Similar to the Ste-Françoise 444 site, a mixed-conifer and broadleaf forest has occupied the dune sands of the Villeroy site 445 between 9700 and 4500 cal yr BP. A conifer forest occupied in part by eastern hemlock 446 and balsam fir established around $1600 \mathrm{cal} \mathrm{yr} \mathrm{BP.} \mathrm{Owing} \mathrm{to} \mathrm{the} \mathrm{occurrence} \mathrm{of} \mathrm{two} \mathrm{fires}$ 447250 and 150 years ago, this stand was replaced by a mixed forest composed of eastern 
448 hemlock, sugar maple, soft maples, balsam fir, birch and aspen. During the last fire of the 449 1920-1930s, however, most conifer species, particularly eastern hemlock, disappeared 450 and were replaced by broadleaf species like red maple, sugar maple and large-toothed 451 aspen. Although red maple is described as intolerant to fire (Abrams 1998), it is the 452 dominant canopy tree of the present Villeroy post-fire stand. Red maple and sugar maple 453 appear well-adapted to fire as they now form the core of the Villeroy forest. Sugar maple 454 is able to produce a large seed crop (Houle 1992) and to resprout after fire (Bilodeau, 455 1992) as it is currently the case for red maple at the Villeroy site. The proximity of the 456 Villeroy bog where mixed red maple-black spruce (Picea mariana)-eastern larch (Larix 457 laricina) wetland stands are widespread is certainly a factor explaining the abundance 458 and expansion of red maple on fire-disturbed well-drained sites.

The most important compositional changes that occurred at the sites recently were associated with a suite of logging and fires separated by short intervals during the last 461 centuries. Pioneer species tolerant to fire disturbance are now dominating the forest 462 landscape, including the red maple stand of Villeroy which has replaced former mixed 463 stands dominated by eastern hemlock. Although sugar maple does not seem to produce a 464 large quantity of charcoal, it is possible that the forest stand of the Ste-Françoise site is of 465 relatively recent origin as it has been shown for other sugar maple stands in Quebec 466 (Pilon and Payette 2015). Contrary to previous expectations about its successional status, 467 sugar maple is a forest tree adapted to conditions prevailing in all the stages of ecological 468 succession. The maple forests of the central St. Lawrence Lowland, including the Ste469 Françoise forest and the Tantaré forest are such good examples. 


\section{Acknowledgements}

472 We are most grateful to Jocelyn Gosselin of the «Direction des inventaires 473 forestiers» of the Québec Department of Forests, Fauna and Parks for initiating and 474 funding this research. We extend our appreciation to Michel Bergeron of the «Direction 475 du patrimoine écologique et des parcs» of the Québec Department of Sustainable 476 Development, Environment and Climatic Change for funding a part of the project 477 dedicated to forest dynamics in sites bordering the Grande-Tourbière-de-Villeroy. We are 478 most grateful to Jason Laflamme, Francis St-Amour and Benoît Filion for assistance in 479 the field and in the laboratory. We thank the reviewers who made constructive comments 480 which increased the quality of the manuscript. 


\section{References}

Abrams, M.D. 1998. The red maple paradox. BioScience 48(5): 355-364. doi:10.2307/1313374

Barber, D.C., Dyke, A., Hillaire-Marcel, C., Jennings, A.E., Andrews, J.T., Kerwin, M.W., Bilodeau, G., McNeely, R., Southon, J., Morehead, M.D., and Gagnon, J.M. 1999. Forcing of the cold event of 8,200 years ago by catastrophic drainage of Laurentide lakes. Nature 400(6742): 344-348. doi:10.1038/22504

Barbour, M.G., and Billings, W.D (editors) 1999. North American Terrestrial Vegetation. $2^{\text {nd }}$ edition. Cambridge University Press. New York, New York.

Bergeron, Y., Bouchard, A., and Leduc, A. 1988. Les successions secondaires dans les forêts du Haut-Saint-Laurent, Québec. Nat. Can. 115(1): 19-38.

Bhiry, N., and Filion, L. 1996a. Mid-Holocene hemlock decline in eastern North America linked with phytophagous insect activity. Quat. Res. 45(3): 312-320. doi:10.1006/qres.1996.0032

Bhiry, N., and Filion, L. 1996b. Characterization of the soil hydromorphic conditions in a paludified dunefield during the Mid-Holocene hemlock decline near Québec City, Québec. Quat. Res. 46(3): 281-297. doi:10.1006/qres.1996.0067

Bilodeau, J. 1992. Écologie des érablières à sucre (Acer saccharum Marsh.) à leur limite nord de distribution au Saguenay-Lac-Saint-Jean. M.Sc. Thesis, Université du Québec à Chicoutimi, Chicoutimi, Québec. 
Bouchard, A., and Maycock, P.F. 1978. Les forêts décidues et mixtes de la région appalachienne du Sud québécois. Nat. Can. 105(5): 383-415.

Bradbury, J.P. 1996. Charcoal deposition and redeposition in Elk Lake, Minnesota., USA. The Holocene 6(3): 339-344. doi:10.1177/095968369600600308

Brisson, J., Bergeron, Y., and Bouchard, A. 1988. Les successions secondaires sur les sites mésiques dans le Haut-Saint-Laurent, Québec, Canada. Can. J. Bot. 66(6): 1192-1203. doi:10.1139/b88-170

Brown, J.-L. 1981. Les forêts du Témiscamingue, Québec. Écologie et photointerprétation. Études écologiques no. 5, Laboratoire d'écologie forestière. Université Laval. Québec, Québec.

Bureau, L. 1968. Les solitudes de Lotbinière. Mémoire de maîtrise. Département de géographie, Université Laval, Québec, Québec.

Carcaillet, C. 2001. Are Holocene wood-charcoal fragments stratified in alpine and subalpine soils? Evidence from the Alps based on AMS ${ }^{14} \mathrm{C}$ dates. The Holocene 11(2): 231-242. doi:10.1191/095968301674071040

Carcaillet, C., and Richard, P.J.H. 2000. Holocene changes in seasonal precipitation highlighted by fire incidence in eastern Canada. Clim. Dyn. 16(7): 549-559. doi:10.1007/s003820000062

Cogbill, C.V. 2000. Vegetation of the presettlement forests of northern New England and New York. Rhodora 102(911): 250-276. 
Courville, S. 1996. Population et territoire. Atlas historique du Québec. Les Presses de l’Université Laval. Québec, Québec.

de Lafontaine, G., and Payette S. 2012. Long-term fire and forest history of subalpine balsam fir (Abies balsamea) and white spruce (Picea glauca) stands in eastern Canada inferred from soil charcoal analysis. The Holocene 22(2): 191-201. doi:10.1177/0959683611414931

Filion, L. 1984. A relationship between dunes, fire and climate recorded in the Holocene deposits of Quebec. Nature 309(5968): 543-546. doi:10.1038/309543a0

Filion, L. 1987. Holocene development of parabolic dunes in the central St. Lawrence Lowland, Québec. Quat. Res. 28(2): 196-209. doi:10.1016/0033-5894(87)90059-7

Filion, L., and Quinty, F. 1993. Macrofossil and tree-ring evidence for long-term forest succession and mid-Holocene hemlock decline. Quat. Res. 40(1): 89-97. doi:10.1006/qres.1993.1059

Filion, L., Lavoie, M., and Querrec, L. 2009. The natural environment of the Québec City region during the Holocene. Post-Medieval Archeology 43(1): 13-29. doi:http://dx.doi.org/10.1179/007942309X12457508843847

Foster, D.R., Motzkin, G., and Slater, B. 1998. Land-use history as long-term broad-scale disturbance: Regional forest dynamics in Central New England. Ecosystems 1(1): 96-119. doi:10.1007/s100219900008 
Frégeau, M., Payette, S., and Grondin, P. 2015. Fire history of the central boreal forest in eastern North America reveals stability since the mid-Holocene. The Holocene 25(12): 1912-1922. doi: 10.1177/0959683615591361

Gauthier, S., and Gagnon, D. 1990. La végétation des contreforts des Laurentides : une analyse des gradients écologiques et du niveau successionnel des communautés. Can. J. Bot. 68(2): 391-401. doi:10.1139/b90-051

Girardin, V. 1969. Étude écologique des érablières de la région du Lac-Saint-Jean. M.Sc. Thesis, Université Laval. Québec, Québec.

Grandtner, M.M. 1966. La végétation forestière du Québec méridional. Les Presses de l’Université Laval. Québec, Québec.

Henry, J.D., and Swan, J.M.A. 1974. Reconstructing forest history from live and dead plant material. An approach to the study of forest succession in southwest New Hampshire. Ecology 55(4): 772-783. doi:10.2307/1934413

Hoadley, R.B. 1990. Identifying Wood: Accurate Results with Simple Tools. Taunton Press, Newtown, Connecticut.

Houle, G. 1992. The Reproductive ecology of Abies balsamea, Acer saccharum and Betula alleghaniensis in the Tantare Ecological Reserve, Quebec. Journal of Ecology 80(4): 611-623. doi: 10.2307/2260853

Inside Wood, 2004 - present. http://insidewood.lib.ncsu.edu/search 
Kindt, R., and Coe, R. 2005. Tree Diversity Analysis: A Manual and Software for Common Statistical Methods for Ecological and Biodiversity Studies. World Agroforestry Centre (ICRAF).

Lafortune, V., Filion, L., and Hétu, B. 2006. Impacts of Holocene climatic variations on alluvial fan activity below snowpatches in subarctic Quebec. Geomorphology 76: $375-391$.

Lavoie, M., and Colpron-Tremblay, J. 2013. Étude paléoécologique de la GrandeTourbière-de-Villeroy. Rapport de recherche. Ministère du Développement durable, de l'Environnement, de la Faune et des Parcs du Québec. Direction du patrimoine écologique et des parcs. Québec, Québec.

Lavoie, M., Colpron-Tremblay, J., and Robert, É.C. 2012. Développement d'une vaste tourbière ombrotrophe non perturbée en contexte périurbain au Québec méridional. Écoscience 19(3): 285-297. doi:http://dx.doi.org/10.2980/19-3-3538

Lorimer, C.G. 1977. The presettlement forest and natural disturbance cycle of northeastern Maine. Ecology 58(1): 139-148. doi:10.2307/1935115

Lorimer, C.G. 1984. Development of the red maple understory in northeastern oak forests. For. Sci. 30(1): 3-22.

Ohlson, M., and Tryterud, E. 2000. Interpretation of the charcoal record in forest soils: Forest fires and their production and deposition of macroscopic charcoal. The Holocene 10(4): 519-525. doi:10.1191/095968300667442551 
Oliver, C.D., and Stephens, E.P. 1977. Reconstruction of a mixed-species forest in Central New England. Ecology 58(3): 562-572. doi:10.2307/1939005

Panshin, A.J., and de Zeeuw, C. 1980. Textbook of Wood Technology. $4^{\text {th }}$ edition. McGraw-Hill, New York, New York.

Payette, S., Delwaide, A., Schaffhauser, A, and Magnan, G. 2012. Calculating long-term fire frequency at the stand scale from charcoal data. Ecosphere 3(7): 59. doi.org/10.1890/ES12-00026.1

Payette, S., Delwaide, A., and St-Amour, F. 2013. Structure et dynamique récente de la tourbière de Villeroy et de ses alentours. Rapport de recherche. Ministère du Développement durable, de l'Environnement, de la Faune et des Parcs du Québec. Direction du patrimoine écologique et des parcs. Québec, Québec.

Payette, S., and Pilon, V. 2014. Structure et dynamique de la prucheraie de la réserve écologique de la Rivière-du-Moulin (comté de Lotbinière, Québec). Rapport de recherche. Ministère des Ressources naturelles du Québec. Direction des inventaires forestiers. Québec, Québec.

Payette, S., Pilon, V., Couillard, P.-L., and Frégeau, M. 2015. Holocene dynamics of an eastern hemlock (Tsuga canadensis) forest site at the northern range of the species limit. The Holocene 25(8): 1246-1256. doi:10.1177/0959683615580863

Pilon, V., and Payette, S. 2015. Sugar maple (Acer saccharum) forests at their northern distribution limit are recurrently impacted by fire. Can. J. For. Res. 45(4): 452-462. doi:10.1139/cjfr-2014-0322 
R Development Core Team, 2011. R: A Language and Environment for Statistical Computing. R Foundation for Statistical Computing. Vienna.

Reimer, P.J.E., Bard, A. Bayliss et al., 2013. IntCal13 and Marine13 radiocarbon age calibration curves 0-50000 years cal. B.P. Radiocarbon 55(4): 1869-1887. doi:10.2458/azu_js_rc.55.16947

Solanki, S.K., Usoskin, I.G., Kromer, B., Schüssler, M., and Beer, J. 2004. Unusual activity of the sun during recent decades compared to the previous 11,000 years. Nature 431(7012): 1084-1087. doi:10.1038/nature02995

St-Jacques, C., and Gagnon, D. 1988. La végétation forestière du secteur nord-ouest de la vallée du Saint-Laurent, Québec. Can. J. Bot. 66(4): 793-804. doi:10.1139/b88-116

Stuiver, M., Reimer, P.J., and Braziunas, T.F. 1998. High-precision radiocarbon age calibration for terrestrial and marine samples. Radiocarbon 40(3): 1127-1151.

Stuiver, M., Reimer, P.J., and Reimer, R.W. 2013. CALIB 7.02. $\underline{\text { http://radiocarbon.pa.qub.ac.uk/calib/ }}$

Talon, B., Payette, S., Filion, L., and Delwaide, A. 2005. Reconstruction of the long-term fire history of an old-growth deciduous forest in southern Québec, Canada, from charred wood in mineral soils. Quat. Res. 64(1): 36-43. doi:10.1016/j.yqres.2005.03.003

Tolonen, M. 1985. Palaeoecological record of local fire history from a peat deposit in SW Finland. Ann. Bot. Fenn. 22(1): 15-29. 
Whitney, G.G. 1994. From Coastal Wilderness to Fruited Plain. Cambridge University Press, Cambridge. 


\section{Tables}

Table 1. Stand characteristics of the Villeroy and Ste-Françoise maple forests.

\begin{tabular}{lcc}
\hline Characteristics & Ste-Françoise & Villeroy \\
\hline Coordinates & $46^{\circ} 27^{\prime} \mathrm{N}$ & $46^{\circ} 22^{\prime} \mathrm{N}$ \\
& $71^{\circ} 53^{\prime} \mathrm{W}$ & $71^{\circ} 48^{\prime} \mathrm{W}$ \\
Altitude & $128 \mathrm{~m}$ & $132 \mathrm{~m}$ \\
Slope & $0-1 \%$ & $1-10 \%$ \\
Thickness (cm) of organic matter & $10.4 \pm 4.7^{a}$ & $3.2 \pm 1.2^{b}$ \\
pH F horizon & 3.5 & $4.2^{b}$ \\
pH B horizon & 3.8 & 4.6 \\
Texture of B horizon & Sandy clay loam & Medium-fine sand \\
\hline
\end{tabular}

${ }^{a} n=25$ (includes dead wood). F and $\mathrm{H}$ horizons are little differentiated.

${ }^{b} n=15$ (2013 data), L and F horizons. Organic matter often buried in mineral soil. 
Table 2. Principal species of the Villeroy and Ste-Françoise maple forests.

\begin{tabular}{|c|c|c|c|}
\hline Layer & Species & Ste-Françoise & Villeroy \\
\hline \multirow{8}{*}{$\stackrel{\Xi}{\Xi}$} & Acer saccharum & $\mathrm{X}$ & $\mathrm{X}$ \\
\hline & Acer rubrum & $\mathrm{X}$ & $\mathrm{X}$ \\
\hline & Betula alleghaniensis & $\mathrm{X}$ & $\mathrm{X}$ \\
\hline & Fagus grandifolia & $\mathrm{X}$ & $\mathrm{X}$ \\
\hline & Fraxinus americana & $\mathrm{X}$ & \\
\hline & Populus grandidentata & & $\mathrm{X}$ \\
\hline & Tilia americana & $\mathrm{X}$ & \\
\hline & Abies balsamea & $\mathrm{X}$ & $\mathrm{X}$ \\
\hline \multirow{8}{*}{$\frac{\hat{Z}}{\tilde{E}}$} & Acer pensylvanicum & $\mathrm{X}$ & $\mathrm{X}$ \\
\hline & Acer spicatum & $\mathrm{X}$ & \\
\hline & Cornus alternifolia & $\mathrm{X}$ & \\
\hline & Cornus canadensis & & $\mathrm{X}$ \\
\hline & Viburnum lantanoïdes & $\mathrm{X}$ & \\
\hline & Lonicera canadensis & $\mathrm{X}$ & \\
\hline & Vaccinium myrtilloides & & $\mathrm{X}$ \\
\hline & Diervilla lonicera & $\mathrm{X}$ & \\
\hline \multirow{16}{*}{ 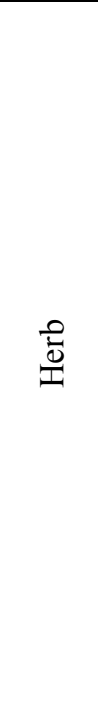 } & Medeola virginiana & $\mathrm{X}$ & $\mathrm{X}$ \\
\hline & Trillium erectum & $\mathrm{X}$ & \\
\hline & Clintonia borealis & $\mathrm{X}$ & \\
\hline & Maianthemum canadense & $\mathrm{X}$ & \\
\hline & Oxalis montana & $\mathrm{X}$ & \\
\hline & Polygonatum pubescens & $\mathrm{X}$ & \\
\hline & Arisaema triphyllum & $\mathrm{X}$ & \\
\hline & Poaceae & & $\mathrm{X}$ \\
\hline & Chimaphila umbellata & & $\mathrm{X}$ \\
\hline & Aralia nudicaulis & $\mathrm{X}$ & \\
\hline & Epifagus virginiana & & $\mathrm{X}$ \\
\hline & Aster sp. & & $\mathrm{X}$ \\
\hline & Dryopteris carthusiana & $\mathrm{X}$ & $\mathrm{X}$ \\
\hline & Pteridium aquilinum & & $\mathrm{X}$ \\
\hline & Huperzia lucidulum & $\mathrm{X}$ & $X$ \\
\hline & Lycopodium dendroideum & & $\mathrm{X}$ \\
\hline
\end{tabular}


Table 3. Number, mass and identification of charcoal pieces of the Ste-Françoise site.

\begin{tabular}{lccc}
\hline Features & Surface & Solum A & Solum B \\
\hline$n$ & $>740$ & 44 & 11 \\
Mean mass $( \pm \sigma)(\mathrm{mg})$ & $4.0 \pm 8.4^{a}$ & $3.3 \pm 4.3$ & $6.2 \pm 8.4$ \\
\hline Picea / Larix laricina & & & 1 \\
Unidentified conifer & & 1 & 1 \\
Betula sp. & 35 & 12 & 2 \\
Broadleaf with spiral thickenings & 24 & 7 & 2 \\
Unidentified broadleaf & 1 & & \\
cf. Acer saccharum & 25 & 20 & 4 \\
Unidentified (bark, pith, parenchyma cells) & 5 & 4 & \\
Unidentified (vitrified, mineralized, altered) & 30 & & \\
Fungi & & & \\
\hline
\end{tabular}

${ }^{a} 565$ samples weigthed. 
Table 4. ${ }^{14} \mathrm{C}$ yr BP, calibrated age (cal yr before 2015), botanical identification of charcoal pieces and number of fire events recorded in the Ste-Françoise site.

\begin{tabular}{|c|c|c|c|c|c|c|c|c|}
\hline 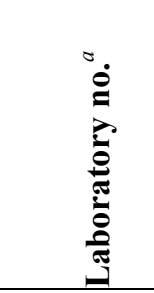 & 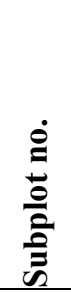 & 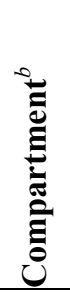 & 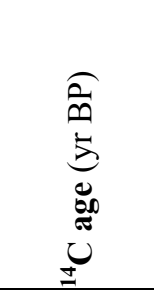 & Identification & 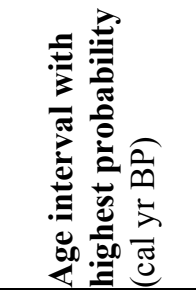 & 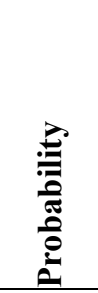 & 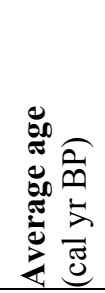 & 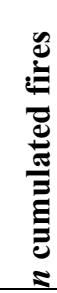 \\
\hline C145371 & 2 & $\mathrm{~S}$ & Modern & Broadleaf with spiral thickenings & & & $\geq 65$ & \\
\hline G18890 & 2 & A & $80 \pm 20$ & Unidentified broadleaf & $97-148$ & 0.49 & 125 & 14 \\
\hline $\mathrm{C} 145375$ & 1 & $\mathrm{~A}$ & $180 \pm 30$ & Broadleaf with spiral thickenings & $201-289$ & 0.57 & 245 & \\
\hline $\mathrm{C} 145592$ & 8 & $\mathrm{~S}$ & $185 \pm 25$ & Broadleaf with spiral thickenings & 205-286 & 0.61 & 245 & \\
\hline C145594 & 2 & $\mathrm{~S}$ & $145 \pm 20$ & Broadleaf with spiral thickenings & 235-296 & 0.34 & 265 & \\
\hline C145374 & 2 & $\mathrm{~A}$ & $145 \pm 30$ & Broadleaf with spiral thickenings & 234-298 & 0.30 & 265 & \\
\hline $\mathrm{C} 145372$ & 5 & $\mathrm{~S}$ & $475 \pm 30$ & Broadleaf with spiral thickenings & $562-606$ & 1.00 & 585 & 12 \\
\hline C145369 & 7 & $\mathrm{~S}$ & $770 \pm 30$ & cf. $A$ & $734-798$ & 1.00 & 765 & \\
\hline C145370 & 1 & $\mathrm{~S}$ & $790 \pm 30$ & Unidentified broadleaf & $737-812$ & 0.98 & 775 & 11 \\
\hline G18895 & $\begin{array}{l}1 \\
9\end{array}$ & A & $950 \pm 20$ & $\begin{array}{l}\text { Unidentified (bark, stem pith, } \\
\text { parenchyma cells) }\end{array}$ & $861-940$ & 0.71 & 900 & \\
\hline $\mathrm{C} 145373$ & 1 & A & $910 \pm 35$ & Unidentified broadleaf & $821-983$ & 0.97 & 900 & 10 \\
\hline C145368 & 5 & $\mathrm{~S}$ & $920 \pm 30$ & Unidentified & 845-986 & 0.98 & 915 & \\
\hline G18892 & $\begin{array}{l}1 \\
0\end{array}$ & A & $930 \pm 20$ & $\begin{array}{l}\text { Unidentified (bark, stem pith, } \\
\text { parenchyma cells) }\end{array}$ & 859-979 & 1.00 & 920 & \\
\hline G18893 & $\begin{array}{l}1 \\
0\end{array}$ & B & $1085 \pm 20$ & $\begin{array}{l}\text { Unidentified (bark, stem pith, } \\
\text { parenchyma cells) }\end{array}$ & -1074 & 1.00 & 1040 & 9 \\
\hline C145573 & 1 & B & $1120 \pm 20$ & Unidentified broadleaf & $1035-1127$ & 1.00 & 1080 & \\
\hline G18889 & 5 & B & $1710 \pm 20$ & $\begin{array}{l}\text { Unidentified (bark, stem pith, } \\
\text { parenchyma cells) }\end{array}$ & $1623-1697$ & 0.73 & 1660 & \\
\hline G18891 & 5 & A & $1720 \pm 20$ & $\begin{array}{l}\text { Unidentified (bark, stem pith, } \\
\text { parenchyma cells) }\end{array}$ & $1628-1703$ & 0.59 & 1665 & \\
\hline C145593 & 2 & S & $2435 \pm 20$ & Broadleaf with spiral thickenit & $2423-2564$ & 0.74 & 2495 & 7 \\
\hline G18896 & 2 & $\mathrm{~B}$ & $6450 \pm 25$ & Betula sp. & $7385-7490$ & 1.00 & 7440 & 6 \\
\hline $\mathrm{C} 145596$ & 2 & $\mathrm{~B}$ & $6710 \pm 25$ & Betula $\mathrm{sp}$ & $7625-7682$ & 0.86 & 7655 & \\
\hline G18897 & 4 & $\mathrm{~B}$ & $6755 \pm 25$ & Unidentified conifer & $7642-7725$ & 1.00 & 7685 & 5 \\
\hline $\mathrm{C} 145571$ & 2 & A & $7015 \pm 25$ & Unidentified broadleaf & $7858-7947$ & 0.63 & 7905 & 4 \\
\hline G18894 & 2 & $\mathrm{~A}$ & $7645 \pm 25$ & Unide & $8454-8528$ & 0.92 & 8490 & \\
\hline $\mathrm{C} 145570$ & 1 & A & $7655 \pm 30$ & Unidentified (vitrified) & $8458-8549$ & 0.84 & 8505 & 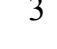 \\
\hline $\mathrm{C} 145588$ & 4 & $\mathrm{~B}$ & $8225 \pm 30$ & Picea sp.-Larix laricina & $9150-9361$ & 0.98 & 9255 & 2 \\
\hline $\mathrm{C} 145595$ & 1 & A & $8825 \pm 30$ & Unidentifed conifer (small stem) & $9791-10018$ & 0.77 & 9905 & 1 \\
\hline
\end{tabular}


Table 5. Number, mass and identification of charcoal pieces of the Villeroy site.

\begin{tabular}{|c|c|c|c|}
\hline & Surface & Solum $\mathbf{A}^{a}$ & Solum B $\mathbf{B}^{b}$ \\
\hline$n$ & $>267$ & 242 & 9 \\
\hline Mean mass $( \pm \sigma)(\mathrm{mg})$ & $7.0( \pm 20.2)$ & $26.4( \pm 13.8)$ & $3.0( \pm 2.0)$ \\
\hline Unidentified (bark, stem pith, parenchyma cells) & 12 & 11 & \\
\hline Unidentified (vitrified, mineralized, altered) & 10 & 26 & 3 \\
\hline Unidentified conifer & 21 & 58 & 2 \\
\hline Taxus canadensis & 1 & 1 & \\
\hline Picea sp. - Larix laricina & 4 & 2 & \\
\hline Abies balsamea & 1 & 1 & \\
\hline Tsuga canadensis & 10 & 14 & \\
\hline Tsuga canadensis - Abies balsamea & 11 & 7 & \\
\hline Tsuga canadensis -Larix laricina & & 8 & \\
\hline Tsuga - Abies - Thuja & 6 & 4 & \\
\hline Unidentified broadleaf $^{c}$ & 18 & 21 & 2 \\
\hline Unidentified broadleaf, shrub ${ }^{d}$ & 6 & 4 & \\
\hline Soft maple (or Rosaceae, Tilia) & 10 & 1 & \\
\hline Acer saccharum & 2 & 0 & \\
\hline Acer sp. & 2 & 4 & \\
\hline Populus sp. & 3 & 49 & \\
\hline Salicaceae & & 31 & \\
\hline Betula sp. & 29 & & 2 \\
\hline \multicolumn{4}{|l|}{25 soil cores } \\
\hline 15 soil cores & & & \\
\hline $\begin{array}{l}\text { Includes several small stems or branches } \\
\text { In the surface compartment: Cornus. Viburnu }\end{array}$ & & & \\
\hline
\end{tabular}


Table 6. ${ }^{14} \mathrm{C}$ yr BP, calibrated age (cal yr before 2015), botanical identification of charcoal pieces and number of fire events recorded in the Villeroy site.

\begin{tabular}{|c|c|c|c|c|c|c|c|c|}
\hline 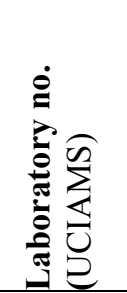 & 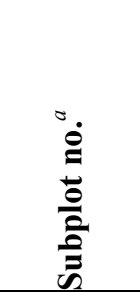 & 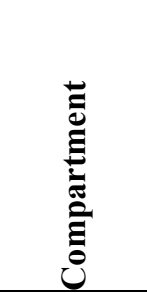 & 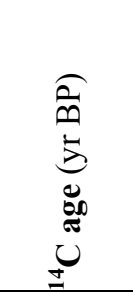 & Identification & 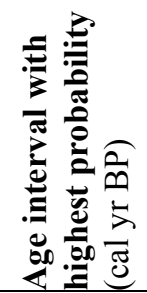 & 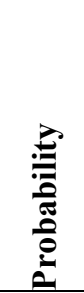 & 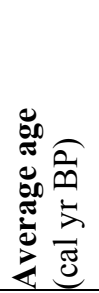 & 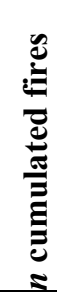 \\
\hline $1 \overline{131936}$ & 19 & $\mathrm{~S}$ & modern & Tsuga -Picea - Larix & & & $\sim 85$ & \\
\hline 123829 & $(10)$ & S & modern & Unidentified broadleaf & & & $\sim 85$ & 16 \\
\hline 124475 & (4) & $\mathrm{S}$ & modern & cf. Tsuga canadensis & & & $\sim 85$ & \\
\hline 131937 & 25 & $\mathrm{~S}$ & $45 \pm 20$ & $\begin{array}{l}\text { Broadleaf with spiral } \\
\text { thickenings }{ }^{b}\end{array}$ & $99-127$ & 0.59 & 115 & \multirow{18}{*}{15} \\
\hline 140576 & 11 & $\mathrm{~S}$ & $80 \pm 15$ & cf. Tsuga canadensis & $98-139$ & 0.54 & 120 & \\
\hline 123828 & (10) & $\mathrm{S}$ & $25 \pm 30$ & Acer sp. & $98-140$ & 0.56 & 120 & \\
\hline 133265 & 25 & A & $70 \pm 20$ & cf. Picea sp. & $97-141$ & 0.48 & 120 & \\
\hline 131011 & Horizon & $30-40 \mathrm{~cm}$ & $75 \pm 20$ & $\begin{array}{l}\text { Picea sp. - Larix } \\
\text { laricina. }\end{array}$ & $97-148$ & 0.53 & 125 & \\
\hline 133267 & 25 & A & $80 \pm 20$ & Taxus canadensis & $97-148$ & 0.49 & 125 & \\
\hline 131932 & Road & & $135 \pm 20$ & $\begin{array}{l}\text { Picea sp. - Larix } \\
\text { laricina }\end{array}$ & $125-185$ & 0.31 & 155 & \\
\hline 124480 & (7) & S & $135 \pm 20$ & Populus sp. & $125-185$ & 0.31 & 155 & \\
\hline 131945 & 19 & $\mathrm{~S}$ & $105 \pm 20$ & Tsuga canadensis & $117-206$ & 0.59 & 160 & \\
\hline 140588 & 16 & S & $110 \pm 15$ & Tsuga canadensis & $122-206$ & 0.61 & 165 & \\
\hline 131025 & Horizon & $\approx 15 \mathrm{~cm}$ & $115 \pm 15$ & $\begin{array}{l}\text { Picea sp. - Larix } \\
\text { laricina. }\end{array}$ & $123-207$ & 0.61 & 165 & \\
\hline 133270 & 16 & A & $115 \pm 20$ & cf. Abies balsamea & $120-210$ & 0.57 & 165 & \\
\hline 131935 & 11 & $\mathrm{~S}$ & $115 \pm 20$ & Abies -Tsuga & $120-210$ & 0.57 & 165 & \\
\hline 140580 & 24 & A & $120 \pm 15$ & Unidentified conifer & 124-209 & 0.60 & 165 & \\
\hline 140589 & 16 & A & $120 \pm 15$ & Unidentified (vitrified) & 124-209 & 0.60 & 165 & \\
\hline 140591 & 15 & A & $120 \pm 15$ & cf. Abies-Tsuga & $124-209$ & 0.60 & 165 & \\
\hline 140586 & & S & $125 \pm 20$ & Tsuga canadensis & $122-213$ & 0.53 & 170 & \\
\hline 131933 & Road & & $130 \pm 20$ & cf. Acer «soft» & $124-214$ & 0.49 & 170 & \\
\hline 131022 & Horizon & $\approx 50 \mathrm{~cm}$ & $190 \pm 15$ & $\begin{array}{l}\text { Picea sp. - Larix } \\
\text { laricina. }\end{array}$ & $211-254$ & 0.47 & 235 & \multirow{12}{*}{14} \\
\hline 133264 & 22 & B & $200 \pm 20$ & Betula sp. & $211-254$ & 0.49 & 235 & \\
\hline 131931 & Road & & $215 \pm 20$ & Abies - Thuja - Tsuga & $214-252$ & 0.51 & 235 & \\
\hline 122736 & (10) & A & $190 \pm 20$ & Acer sp. & $209-280$ & 0.61 & 245 & \\
\hline 122733 & (10) & A & $195 \pm 20$ & Acer sp. & $210-279$ & 0.60 & 245 & \\
\hline 122734 & (10) & A & $180 \pm 20$ & Acer sp. & $207-284$ & 0.62 & 245 & \\
\hline 131944 & 19 & $\mathrm{~S}$ & $180 \pm 20$ & Betula sp. & $207-284$ & 0.62 & 245 & \\
\hline 131947 & Road & & $170 \pm 20$ & cf. Acer «soft» & $230-287$ & 0.51 & 260 & \\
\hline 133269 & 25 & A & $170 \pm 20$ & Populus sp. & $230-287$ & 0.51 & 260 & \\
\hline 124482 & (9) & $\mathrm{S}$ & $165 \pm 20$ & Abies-Tsuga cf. Tsuga & $231-289$ & 0.50 & 260 & \\
\hline 131946 & 21 & $\mathrm{~S}$ & $160 \pm 20$ & Shrub broadleaf ${ }^{c}$ & $232-289$ & 0.47 & 260 & \\
\hline 140587 & (8) & $\mathrm{S}$ & $160 \pm 15$ & Tsuga canadensis & $234-287$ & 0.53 & 260 & \\
\hline
\end{tabular}




\begin{tabular}{|c|c|c|c|c|c|c|c|c|}
\hline 131943 & 16 & S & $155 \pm 20$ & $\begin{array}{l}\text { Broadleaf with spiral } \\
\text { thickenings }^{b}\end{array}$ & $233-290$ & 0.43 & 260 & \\
\hline 124481 & (7) & S & $145 \pm 15$ & Acer sp. & $237-290$ & 0.36 & 265 & \\
\hline 124484 & (6) & S & $150 \pm 20$ & cf. Tsuga canadensis & $234-293$ & 0.39 & 265 & \\
\hline 122732 & (6) & A & $150 \pm 25$ & Betulaceae & $233-296$ & 0.36 & 265 & \\
\hline 124483 & (7) & $\mathrm{S}$ & $305 \pm 15$ & Abies balsamea & $423-495$ & 0.76 & 460 & 13 \\
\hline 131934 & Road & & $420 \pm 20$ & Conifer (except Pinus) & $529-579$ & 1.00 & 555 & 12 \\
\hline 140577 & 15 & B & $1170 \pm 20$ & Unidentified (vitrified) & $1118-1241$ & 0.93 & 1180 & 11 \\
\hline 140578 & 20 & A & $1305 \pm 15$ & $\begin{array}{l}\text { Shrub (small altered } \\
\text { stem) }\end{array}$ & $1300-1352$ & 0.73 & 1325 & 10 \\
\hline 131015 & Horizon & $30-50 \mathrm{~cm}$ & $1545 \pm 20$ & $\begin{array}{l}\text { Picea sp. - Larix } \\
\text { laricina. }\end{array}$ & $1516-1587$ & 0.61 & 1550 & \multirow{3}{*}{9} \\
\hline 134712 & 20 & A & $1540 \pm 20$ & Tsuga canadensis & $1517-1587$ & 0.55 & 1550 & \\
\hline 140590 & 22 & A & $1625 \pm 20$ & Abies -Tsuga & $1581-1631$ & 0.73 & 1605 & \\
\hline 133268 & 19 & A & $3675 \pm 20$ & Unidentified (vitrified) & $4028-4150$ & 0.93 & 4090 & \multirow{2}{*}{8} \\
\hline 140581 & 19 & A & $3685 \pm 15$ & Unidentified (vitrified) & $4042-4149$ & 1.00 & 4095 & \\
\hline 140585 & 16 & B & $3945 \pm 20$ & Unidentified conifer & $4445-4506$ & 0.68 & 4475 & 7 \\
\hline 122735 & (2) & $\mathrm{A}$ & $4315 \pm 30$ & Unidentified broadleaf & $4903-4959$ & 0.72 & 4930 & 6 \\
\hline 133266 & 21 & $\mathrm{~A}$ & $7465 \pm 25$ & Unidentified (vitrified) & $8340-8425$ & 0.55 & 8385 & 5 \\
\hline 140579 & 11 & $\mathrm{~A}$ & $7675 \pm 25$ & Unidentified conifer & $8476-8587$ & 0.96 & 8530 & 4 \\
\hline 140575 & 22 & $\mathrm{~A}$ & $8230 \pm 25$ & Unidentified (vitrified) & $9180-9358$ & 0.98 & 9270 & 3 \\
\hline 122731 & (2) & $\mathrm{A}$ & $8365 \pm 25$ & Unidentified broadleaf & $9436-9532$ & 0.67 & 9485 & 2 \\
\hline 131936 & (6) & A & $8650 \pm 25$ & Unidentified broadleaf & $9607-9732$ & 1.00 & 9670 & 1 \\
\hline
\end{tabular}

Shaded lines: Charcoal beneath the road bordering the Villeroy stand and charcoal buried in nearby dune sands and peat deposits.

${ }^{a}$ Subplots in parenthesis were sampled in 2012.

${ }^{b}$ Acer $«$ soft»-Tilia-Rosaceae

${ }^{c}$ Cornus-Viburnum-Ericaceae 


\section{Figure captions}

Figure 1. Tree size structure of the Ste-Françoise (upper pannel) and the Villeroy (lower pannel) stands.

Figure 2. Distribution of the sum of cumulated probabilities of calibrated ${ }^{14} \mathrm{C}$ charcoal dates. Grey shadings correspond to probability areas showing the time intervals of fire dates based on the greatest probability distribution. Each sign $\mathrm{x}$ indicates the occurrence of a fire event centered on the mean of the greatest probability interval of one or several radiocarbon dates (A) and average accumulation curve of number of charcoals dated and fires detected (B) in the Ste-Françoise site. The accumulation curve $F(n)=F(\max )$ (1$\left.e^{\mathrm{kn}}\right)$, is the average of a 100 iterations where $F(n)$ is the number of fires detected, $n$ is the number of charcoal fragments dated, $F(\max ) \pm 1 \sigma$ is the estimated number of fires (asymptote) and $\mathrm{k}$ is the constant.

Figure 3. Distribution of the sum of cumulated probabilities of calibrated ${ }^{14} \mathrm{C}$ charcoal dates. Grey shadings correspond to probability areas showing the time intervals of fire dates based on the greatest probability distribution. Each sign $\mathrm{x}$ indicates the occurrence of a fire event centered on the mean of the greatest probability interval of one or several radiocarbon dates (A) and average accumulation curve of number of charcoals dated and fires detected (B) in the Villeroy site. The accumulation curve $F(n)=F(\max )\left(1-e^{k n}\right)$, is the average of a 100 iterations where $F(n)$ is the number of fires detected, $n$ is the number of charcoal fragments dated, $\mathrm{F}(\max ) \pm 1 \sigma$ is the estimated number of fires (asymptote) and $\mathrm{k}$ is the constant.

Figure 4. Number of dated charcoal fragments per 250 cal years BP class in the Villeroy (this study, $46^{\circ} 22^{\prime} \mathrm{N}, 71^{\circ} 48^{\prime} \mathrm{W}$ ), Ste-Françoise (this study, $46^{\circ} 27^{\prime} \mathrm{N}, 71^{\circ} 53^{\prime} \mathrm{W}$ ), RivièreÉternité $\left(48^{\circ} 16^{\prime} \mathrm{N}, 70^{\circ} 28^{\prime} \mathrm{W}\right.$ ) and Tantaré (Talon et al. $2005 ; 47^{\circ} 04^{\prime} \mathrm{N}, 71^{\circ} 32^{\prime} \mathrm{W}$ ) sites. 

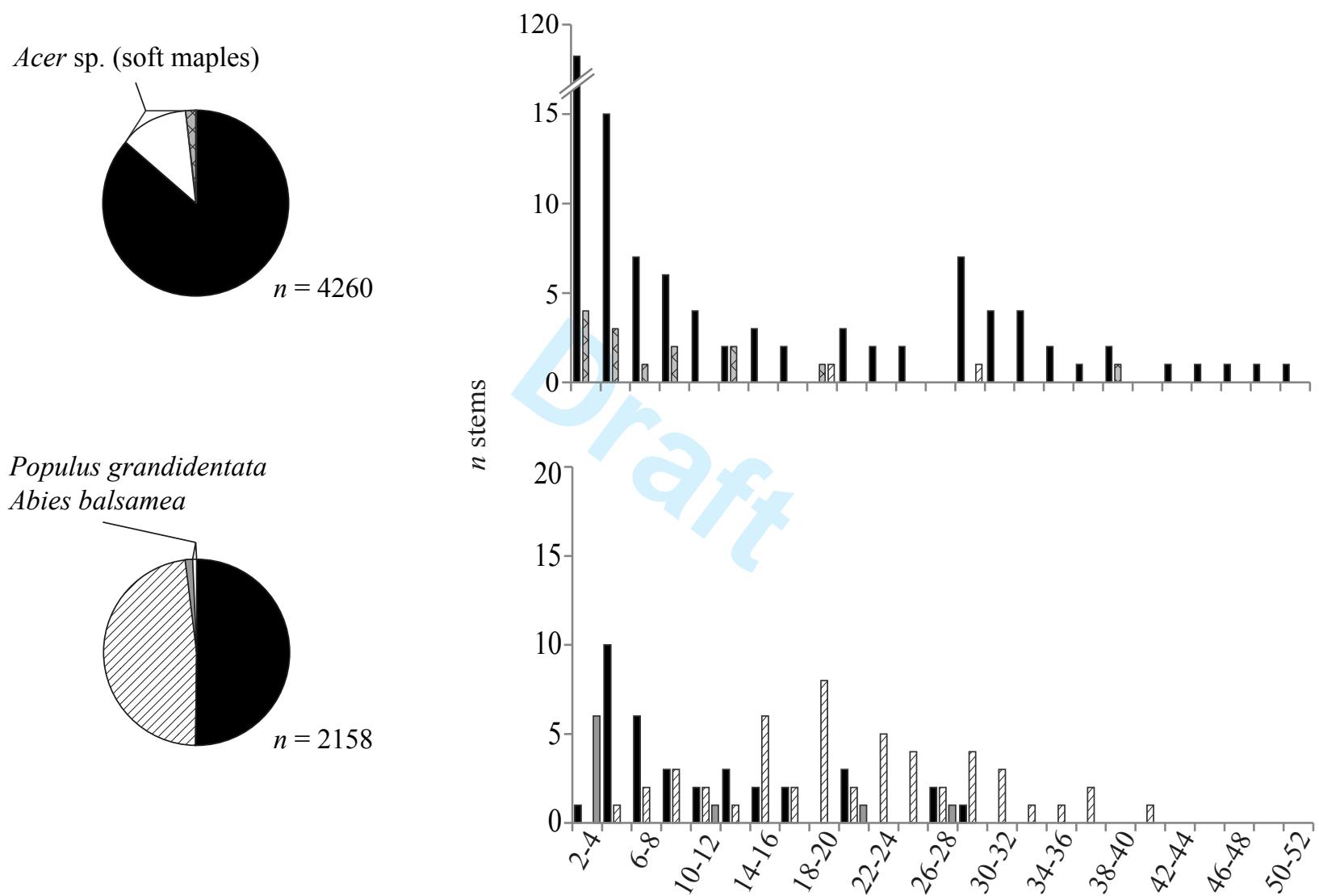

Populus grandidentata Abies balsamea

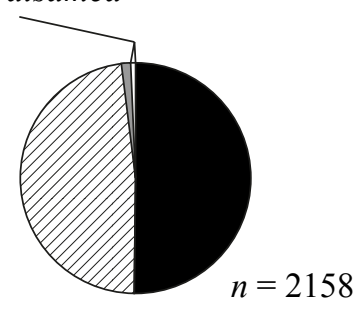

DBH (2-cm classes) https://mc06.manuscriptcentral.com/cjfr-pubs 


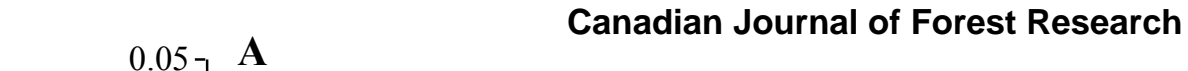

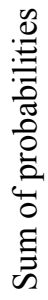

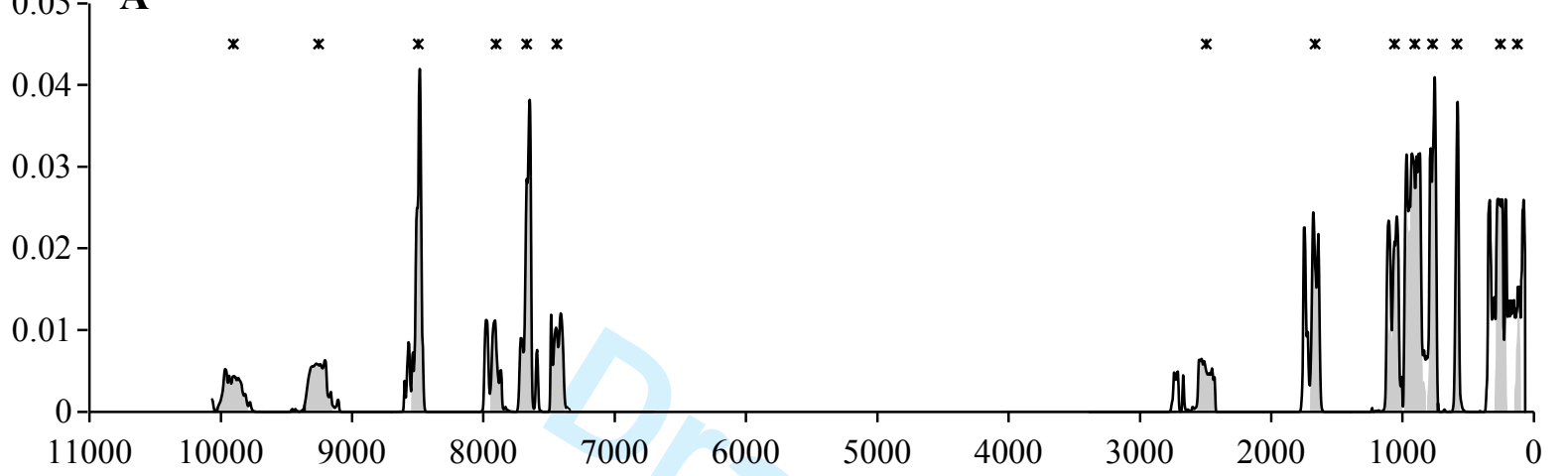

U్త

cal yr BP

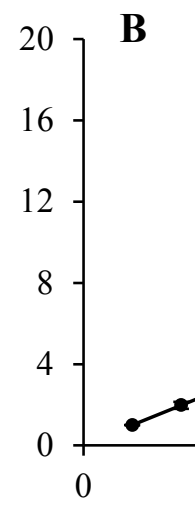

( Estimated number of fires $(\operatorname{Fmax} \pm 1 \sigma)=18 \pm 0.11$

$$
\mathrm{k}=-0.06
$$

5 https://mc06. manuscriptcehtral.com/cjfr-p20 bs

25 

Canadian Journal of Forest Research
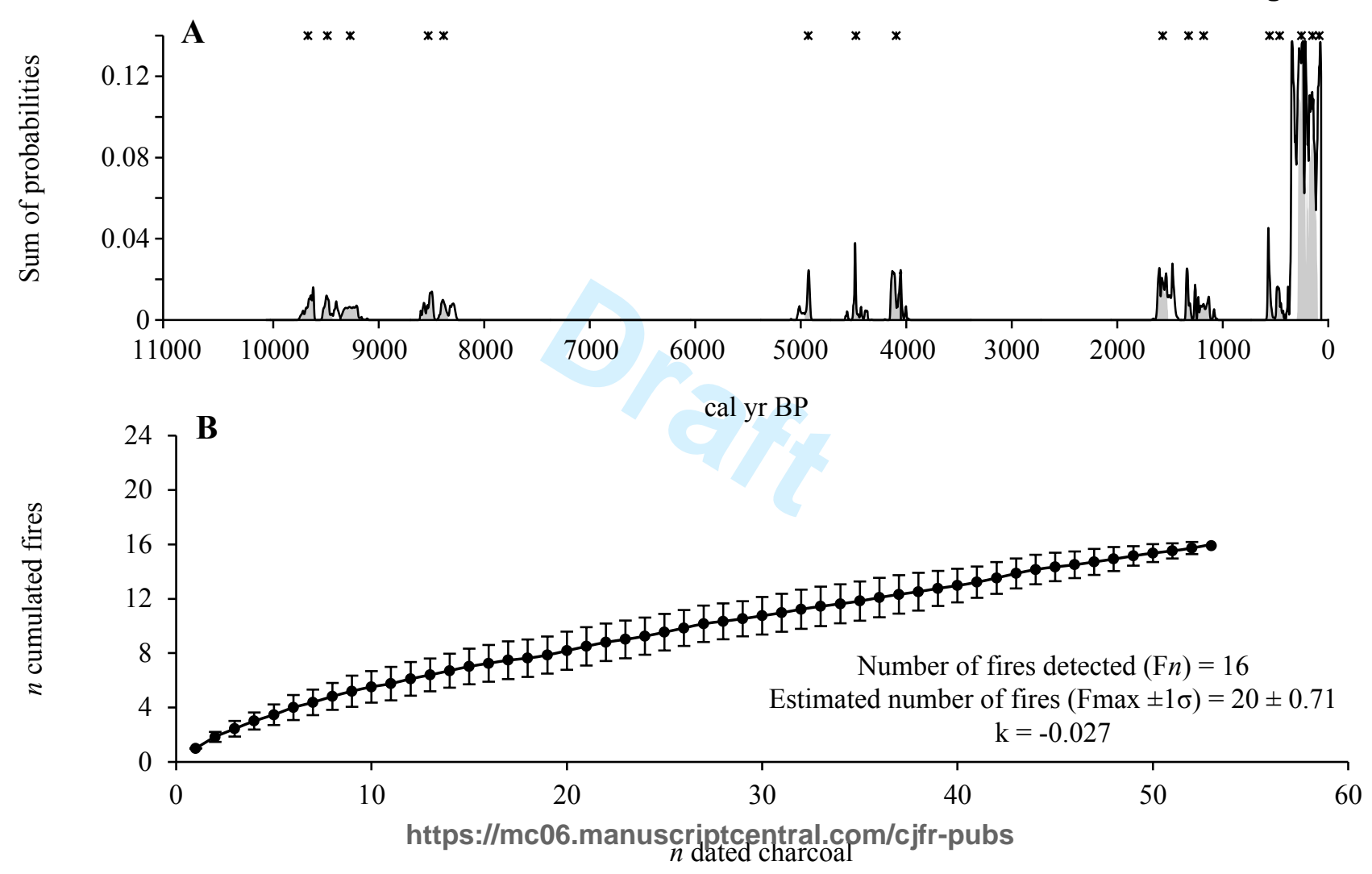
Page earufienten Journal of Forest Research

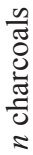

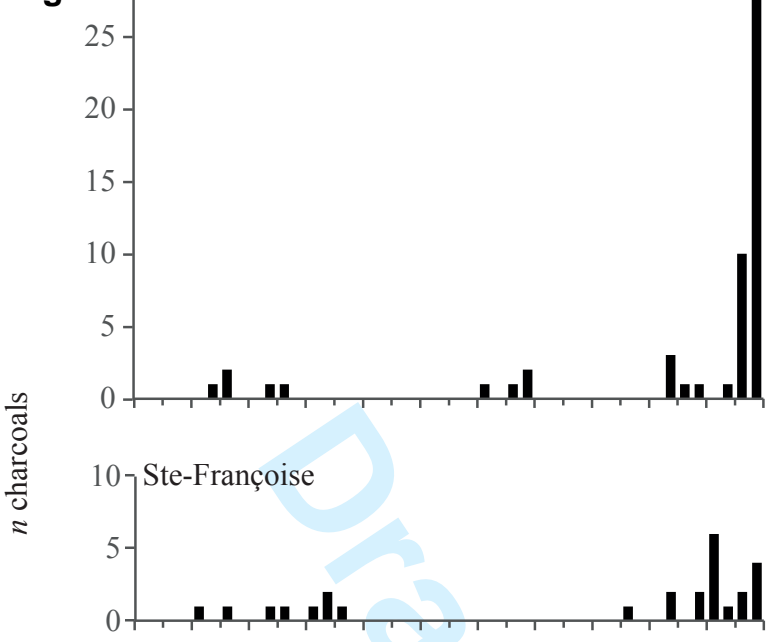

10 Rivière-Éternité

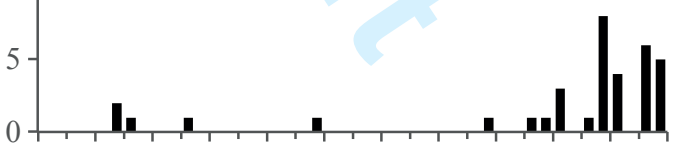

10 Tantaré

5

0 
